\title{
学会記 事
}

\section{6 年年会記事}

2016年(平成28年)9月23日(金)より9月25日(日)まで，金沢大学角 間キャンパス自然科学研究科講義棟等において，金沢大学，金沢 大学理工研究域の後援を受け, 日本鉱物科学会2016年年会・総会 を開催しました。セッション形式による口頭講演, ポスター講演 に加え, 今年はシンポジウムを開催しました。その他, 例年通り, 秘親会, 総会, 評議員会, 各種委員会, 学会賞等受賞講演を行い ました。(一般社団法人移転審議が行われた総会内容や受賞者紹介 は岩石鉱物科学 45 巻 6 号 161 頁以降と学会HPに掲載されています のでご覽ください。)

発表講演総数は237件(シンポジウム6件，口頭138件，ポスター93 件)でした。今年は9月24日(土)14:00～16:30にシンポジウム「ちきゅ う掘削鉱物科学」を開催し, 一般にも公開され地元の高校生にも多 数参加いただきました。その他スペシャルセッション2件とレギュ ラーセッション8件 $(\mathrm{R} 7$ : 岩石・鉱物・鉱床一般は資源地質学会と共 催)を開催しました。

また, 参加者総数は279名(一般正会員177名, 学生正会員48名, 非会員一般16名, 非会員学生37名, 招待講演者1名)であり, 懇親会 参加者総数は135名(一般112名, 学生23名)でした。懇親会はKKR木 テル金沢で開催し，参加者同士の親睦がおおいに深められました。

なお， 総会後半に行われた，一般社団法人化記念事業の一環で ある「日本の石」の選定が会員の投票で行われました。詳細は「岩 石鉱物科学 45 巻 6 号 170 頁」と学会HPに掲載されていますのでご覧 ください。6社の展示広告業者にご協力いただきましたことと， 金沢市と石川県からの補助金支援に厚く御礼申し上げます。

\section{日本鉱物科学会2016年年会研究発表優秀賞受賞者}

第38回受賞者 菊池 亮佑(東大・院理)

R4-P03 : 加水黒雲母の層間内におけるセシウムの拡散速度の 定量

第39回受賞者 鈴木 康太(神戸大・院理)

R5-24 : 雰囲気制御ガス浮遊システムの開発: コンドリュール 組織の再現を目指して

第40回受賞者 木村 泉史(東大・院理)

R6-02 : 早池峰-宮守オフィオライト中の超苦鉄質貫入岩から 推定する融解機構とオルドビス紀マントルの熱状態

第41回受賞者 伊神 洋平(京都大・院理)

R8-P09：東南極Napier岩体に産する珪線石の最高経験温度推 定一TEMによる微細組織観察と $\mathrm{Al} / \mathrm{Si}$ 秩序度分析一

2016年年会運営委員会 :

奥野正幸（委員長）

荒井章司, 海野 進(副委員長), 森下知晃(副委員長), 酒寄 淳, 奥寺浩樹, 福士圭介, 水上知行, 演田麻希, 田村明弘, 荒砂 茜, 曽田祐介, 豊田丈紫

黒澤正紀(行事幹事), 角替敏昭(行事副委員長), 磯部博志(" )

【お知らせ】毎年年会記事欄で報告していた年会会計決算報告です が,一般社団法人化後は学会会計決算書に含まれて定時総会の承認 が必要となりました。ついては2016年年会会計は2017年(平成29年) 8 月 12 日に小山内康人監事により監査を受け，平成 29 年 9 月 12 日の平 成28年度一般社団法人日本鉱物科学会定時総会にて平成 28 年度決 算書（計算書類及び付属明細書）として承認されましたことを報告 します。決算書（計算書類及び付属明細書）は平成28年度定時総会 議事録に掲載します。

\section{6年年会研究発表優秀賞受賞者 渡航支援制度 成果報告}

2015年から年会で発表講演し, 研究発表優秀賞を受賞した学生会 員に対し, 海外の学会等で研究成果を発表する或は海外で調査・ 研究を行うことを支援するための奨励金を設けております。 昨年の2016年年会研究発表優秀賞受賞者のうち2名の受賞者が支 援を受けましたので，以下に 成果の報告をします。

\section{東京大学大学院理学系研究科 M2 木村馡史}

（2016年年会研究発表優秀賞 受賞者）

1.支援内容: International Winter School: Melting and fluid/melt-rock reactions in the mantle $\frown$ の参加 旅費

2. 場所: パビア (イタリア)

3. 日程: 2017 年 2 月 $13 \sim 17$ 日

内容詳細 :

2017年2月にイタリアのパビアで開催されたInternational Winter School, Melting and fluid/melt-rock reactions in the mantleに参加し た。スクールでは様々な国のPh.D. 学生らと寝食を共にしながら, マントル岩石学, 地球化学等に関して基礎から最新の研究成果ま での講義を受けた。また講義後にはポスターセッションが行われ た。私は，島弧オフィオライトから制約できる上部マントルの熱 史に関してポスター発表を行った。

自身とって初の国際舞台であったため序盤は怖じ気づいたが, 恥をかく覚悟が固まって以降は恐怖が消え, 最終的に様々な国の 研究者と議論し交流を深めることができた。また同世代の友人・ ライバルもできた。この経験は私の国際性に関する姿勢を大いに 刺激した。博士課程進学後もさらに研究に精進したい。スクール を紹介してくださった金沢大学の森下先生，海外渡航支援制度関 係者の皆様に厚く御礼申し上げる。

\section{東京大学大学院理学系研究科 D2 菊池亮佑} （2016年年会研究発表優秀賞 受賞者）

1. 支援内容 : 16th International Clay Conference 学会発表 旅費

2. 場所 : グラナダ

3. 日程 : 2017年7月17日〜21日

内容詳細 :

スペインのグラナダにて開催された国際学会”16th International Clay Conference" $の$ Clay Minerals in Sediments: Paleoenvironment; Geodynamic Evolution and Sedimentary Basinsのセッションにて Mineralogy and chemistry of biotite in the weathering profile of granitic rocks in the eastern part of Fukushima Prefecture, Japanという題目で 口頭発表を行いました。この国際学会では自分の博士研究のテー マである花崗岩風化帯中の黒雲母の風化に関して, 特にバーミキ ユライト化と層電荷の空間的関係に焦点を絞って発表しました。 開催期間中は地球科学に留まらず，材料科学・計算科学を含めた 他分野の粘土鉱物に関する最新の成果を知ることができ, 非常に 充実した5日間でした。X線回折や電子顕微鏡法など従来の分析手 法にもまだまだ発展の余地を感じましたし，新しい分析方法に関 する知識や今後の実験のアイデアを得ることができました。同時 に，日本国内における粘土鉱物科学をより盛り上げていく必要性 を再確認しました。このような貴重な発表機会を支援して頂いた 日本釷物科学会, 並びに研究をご指導頂いた先生方に厚く御礼申 し上げます。 


\section{一般社団法人日本鉱物科学会 平成28年度第 1 回 定例理事会議事録}

1. 招集通知年月日：平成28年(2016年)9月 12 日

2. 開催年月日及び時刻：平成28年(2016年)9月24日(土) 16時35分から18時00分

3. 開催場所 : 金沢大学角間キャンパス自然科学本館

于920-1192 石川県金沢市角間町

1 階レクチャーホール

4. 理事総数および定数 : 総数 32 名, 定足数 17 名

5. 出席理事数 29 名

出席 : 土山 明, 榎並正樹, 大藤弘明, 鍵 裕之, 貴治康夫, 佐藤 努, 角替敏昭, 永嶌真理子, 濱本拓志, 平島崇男, 宮島 宏, 森下知晃, 阿部なつ江, 井上 徹, 小暮敏博, 下林典正, 高澤栄一, 長瀬敏郎, 中村美千彦, 安東淳一, 大和田正明, 河上哲生, 川本竜彦, 鈴木正哉, 永井隆哉, 伴 雅雄, 三河内岳, 宮脇律郎, 吉朝 朗

久席 : 上原誠一郎, 黒澤正紀, 土谷信高

出席監事 : :小山内康人

6. オブザーバー：(幹事会メンバー就任予定者)

出席 : 会計幹事 : 栗林貴弘, JpGUプログラム委員 : 門馬綱一, 事務局

欠席: JpGUプログラム委員 : 齊藤哲, JpGU連絡委員 : 大谷栄治

\section{7. 議事概要}

定足数 17 名を超える29名の理事が出席し, 定款30条により理事会 が成立したことを確認したのち, 土山明会長が議長となり第1回理 事会を開始した。

\section{I. 報告事項}

1. 理事, 監事の選任報告と任意団体日本鉱物科学会解散決議など 旧総会報告(土山明会長，代表理事)

土山会長から一般社団法人日本鉱物科学会理事, 監事の選任報告 と任意団体日本鉱物科学会解散決議など旧総会の報告があった。

1) 理事:

土山 明 (会長), 榎並正樹 (副会長)

大藤弘明, 鍵 裕之, 貴治康夫, 佐藤 努, 角替敏昭, 永嶌真理子, 濱本拓志, 平島崇男, 宮島 宏, 森下知晃, 阿部なつ江, 井上 徹, 上原誠一郎, 黒澤正紀, 小暮敏博, 下林典正，高澤栄一，土谷信高，長瀬敏郎，中村美千彦， 安東淳一, 大和田正明, 河上哲生, 川本竜彦, 鈴木正哉, 永井隆哉, 伴 雅雄, 三河内岳, 宮脇律郎, 吉朝 朗

2) 監事: 小山内康人

3）一般社団法人設立と任意団体解散の報告

平成28年8月中に設立社員2名, 設立理事32名（先の選挙当選者 12 名之継続 20 人で, 設立代表理事 2 名, 設立平理事 30 名）と監事 1 名からの就任承諾書提出, 8 月 26 日に公証人による定款の認証後, 平成28年9月1日にすべての書類が代理人の司法書士により東京 法務局（仙台法務局管轄）に提出され登記が完了し，一般社団法 人日本鉱物科学会が設立されたことが報告された。また, 平成 28 年9月 22 日任意団体日本鉱物科学会第3回評議員会にて任意団体 日本鉱物科学会解散の件が審議承認され, 続いて平成 28 年 9 月 24
日の任意団体日本鉱物科学会平成 27 年度総会にて審議の後平成 28年9月 28 日をもって解散することが満場一致で承認されたこと が報告された。

\section{2.「日本の石」選定結果報告 （土山明国石選定WG委員長）}

土山日本の石選定WG委員会から，以下の報告があった。 日本鉱物科学会は社団法人化の記念事業の一環として進めてき た，日本の石すなわち「国石」の選定事業における会員による最終 投票を行った。第 1 回目の投票結果は, ひすい 48 票, 水晶 35 票, 輝 安鉱 23 票, 自然金 10 票, 花崗岩 8 票と, どれも過半数に達しなかっ た。投票前の申し合わせに従い，上位 2 候補について決選投票を行 った結果, ひすい 71 票, 水晶 52 票となり, 有効得票数の過半数とな った「ひすい（ひすい輝石及びひすい輝石岩）」が国石として選定 された。

3. 年会開催準備報告

1） 2017年年会 (愛媛大学) 開催状況報告（井上理事）

井上理事から以下の報告があった。

・日時 : 2017年9月12日(火)〜 14日(木)

・場所 : 愛媛大学理学部講義棟・数学棟 (一般講演・ポスター) 愛媛大学南加記念ホール (総会・受賞記念講演会)

・2017年年会運営委員会(LOC) :

入舩徹男(委員長), 井上 徹, 土屋卓久, 大藤弘明, 西原 遊, 土屋 旬, 境 毅, 大内智博, 西 真之, 新名 亨, 森 寛志, 齊藤 哲，榊原正幸，佐野 栄(以上予定)

・日程：9月12日（火）午前 総会・受賞記念講演会 (愛媛大学南加記念ホール) 9月12日 (火) 午後から一般講演（愛媛大学理学部講義棟） 懇親会は 1 日目の夕方, 愛媛大学生協にて。

・巡検 : 行わない。

・シンポジウム：「地球深部関係」のシンポジウムを行いたい。 同時期に「触媒学会」，「プロテイン・アイランド・松山 国際シ ンポジウム」が開催される。日本地質学会は，2017年9/15(金)日 本地質学会主催一般公開講演会, 愛媛大学2017年9/16(土) 18 (月・祝) 日本地質学会愛媛大学, 19(火) 日本地質学会主催の巡検 とのことで学会が集中

2) 2018年開催地(山形大学)の件状況報告（伴 理事) 伴理事から以下の報告があった。

2018年の山形での年会開催に関して, 平成28年6月2日にLOCの第 1 回目の会議を開催した。

・開催日：平成30年9月19〜21日を第一候補に考えているが，地質 学会の日程がまだ決まっていないので連絡を取りながら調整し ていく。

- 会場 : 山形大学

・2018年日本鉱物科学会年会運営委員会メンバー 年会運営委員会委員長 : 中島和夫 連絡調整担当 (副委員長) : 伴雅雄 会場・案内担当 : 加々島慎一, 物品調達担当 : 湯口貴史 (2018年 行事委員), 懇親会担当: 大友幸子, 加々島慎一, アルバイト担 当 : 湯口貴史, 中島和夫，会計担当 : 岩田尚能，伴雅雄，巡検担 当 : 大友幸子, 中島和夫, 伴雅雄, 生協担当 : 岩田尚能

4.その他

会長からWRI（Water -Rock Interaction）2019年国際会議について鉱 物科学会を中心に日本で開催する旨の招致活動を承認したことが 報告された。 


\section{II. 審議事項}

第 1 号議案 新入会承認の件

佐藤務理事, 会員幹事より入会者の申し込みがなかったことが報 告された。

第2号議案 幹事, 各委員会委員長, 委員承認の件

土山会長から以下の (1) から(20)までの幹事, 各委員会委員につい て紹介があり，承認された。なお，(13)から(19)の新規，継続委員 は後日選出することで了承された。

(1) 幹事会メンバー

会 長 : 土山 明, 副会長 : 榎並正樹, 庶務幹事 : 中村 美千彦 会員幹事 : 佐藤 努, 会計幹事 : 栗林貴弘, 行事幹事 : 黒澤正紀 和文誌編集幹事 : 長瀬敏郎, 英文誌編集幹事: 平島崇男, 渉外幹 事: 川本竜彦，広報幹事 : 伴 雅雄, Elements幹事: 片山郁夫 特務幹事（細則等検討担当）：大和田正明，特務幹事（会員増対 策担当）: 吉朝 朗，三鉱連絡委員：中村美千彦，黒澤正紀， 地球惑星科学連合2017年度学会選出プログラム委員 : 齊藤 哲

(正)・門馬綱一(副)，地惑連合連絡担当 : 大谷栄治

(2) 行事委員会

委員長 : 黒澤正紀 行事幹事 副委員長 : 角替敏昭, 磯部博志 委員: 井上 徹 (2017年LOC委員) 鍵 裕之, 片山郁夫, 河上哲生，橘 省吾，寺崎英紀

\section{(3) 岩石鉱物科学編集委員会}

委員長 : 長瀬敏郎 和文誌編集幹事 副委員長 : 高澤栄一

委 員 : 阿部なつ江，荒川洋二，石渡 明，上原誠一郎， 大藤弘明，加藤 工， 掛川 武，木村純一， 木村 䢐, 興野 純, 久保友明, 栗谷 豪, 栗林貴弘, 小暮敏博, 近藤 忠, 柴 正敏, 下林典正, 高須 晃, 土谷信高, 中井 泉, 中村美千彦，永嶌真理子，西戸裕嗣，野口高明， 長谷中利昭, 演田麻希, 林謙一郎, 林信太郎, 伴 雅雄, 坂野靖行, 平島崇男, 藤縄明彦, 星出隆志, 牧野州明, 三宅 亮, 宮島 宏, 村田 守，門馬綱一，坑本尚義，吉朝 朗

新委員：㴿田麻希（金沢大), 久保友明（九大）, 三宅 亮 (京大), 星出隆志（秋田大）

\section{(4) JMPS編集委員会}

委員長 : 平島崇男 英文誌編集幹事 副委員長：吉朝 朗, M. Satish-Kumar

委 員 : 伴 雅雄, 榎並正樹, 藤本光一郎, 林謙一郎, 井上 徹, 石渡 明, 加藤丈典, 河野元治, 木村純一，小木曽哲，興野 純，松枝大治， 三河内岳, 中村美千彦, 小畑正明, 大谷栄治, 奥寺浩樹， 大和田正明，佐藤 努，佐脇貴幸， 篠田圭司，下林典正， 杉山和正，角替敏昭， 宇都宮聡，Jung Ho Ahn， Richard J. Arculus,

D. Chandrasekharam, Ming Chen, Moonsup Cho, Alexander Khanchuk, Anhuai Lu, Joseph R. Smyth

(5) 渉外委員会

委員長 : 川本竜彦(岩石関係) 涉外幹事

委 員: 栗谷豪(火山), 辻森 樹 (地質), 井上 徹 (高圧), 永嶌真理子 (鉱物)，宇都宮聡 (環境)
（6）広報委員会

委員長 : 伴 雅雄 広報幹事

委 員 : 奥村 聡,亀井淳志，橘 省吾, 門馬綱一, 中村美千彦 (庶 務幹事)

(7) Elements 委員会

委員長 : 片山郁夫 Elements幹事 副委員長 : 興野 純

学会役職指定委員：中村美千彦 (庶務), 長瀬敏郎 (GKK), 平島崇男 (JMPS)，黒澤正紀 (行事)， 川本竜彦 (渉外) 伴 雅雄(広報)

Society News Editor : 片山郁夫

Executive Committee Member：土山 明（会長）

委員 : 宇都宮聡, 森下知晃, 鍵 裕之, 井上 徹, 寺崎英紀， 橘 省吾，宮脇律郎，横山 正

(8) 新鉱物・命名 - 分類委員会

$$
\text { (サイエンスボード) }
$$

委員長 : 宮脇律郎

委 員: 上原誠一郎, 小林祥一, 清水正明, 坂野靖行, 松原 聰. 浜根大輔, 門馬綱一

(9) 教育普及委員会

委員長 : 奥山康子

委 員: 貴治康夫, 林信太郎, 宮島 敏, 川手新一

(10) 博物館委員会

委員長 : 坂野靖行

委 員 : 宮脇律郎, 宮島 宏, 長瀬敏郎, 森 康

(11) 日本鉱物科学会賞選考委員会

委員長 : 井上 徹 副委員長 : 高澤栄一

委 員 : 阿部なつ江，上原誠一郎，黒澤正紀，小暮敏博， 下林典正，土谷信高，長瀬敏郎， 中村美千彦，(会長)土山 明

(12) 櫻井賞選考委員会

委員長 : 松原 聰

委 員: 中井 泉, 清水正明, 宮脇律郎, 坂野靖行, 宮島 宏

(13) 将来企画委員会（委員10名）

委員長 : 榎並正樹（副会長）副委員長 : 今後選出予定

委員 : 今後選出予定

オブザーバー：土山 明 (会長)

(14) 細則等検討委員会 (委員5名)

委員長 : 大和田正明委 員 : 今後選出予定

オブザーバー : 榎並正樹（副会長）

（15）渡邊萬次郎賞選考委員会 :

委員 8 名で，毎年その半数が交代し，再任は妨げない。 委員長 : 宮脇律郎副委員長 : 今後選出予定

委 員 : (1期目選出委員4名) 今後選出予定 (2期目継続委員4名) 大和田正明，高澤栄一，平島崇男，宮脇律郎(委員長)

（16）日本鉱物科学会論文賞選考委員会：

委員10名で，毎年その半数が交代し，再任は妨げない。 委員長 : 角替敏昭 副委員長 : 今後選出予定 
委 員 : (1期目選出委員5名) 今後選出予定

(2期目継続委員 5 名 $)$ :

鍵裕之, 川本竜彦, 森下知晃, 吉朝朗, 角替敏昭(委員長)

(17) 日本鉱物科学会研究奖励賞選考委員会 :

委員 10 名で，毎年その半数が交代し，再任は妨げない。

委員長 : 安東淳一副委員長 : 今後選出予定

委 員：(1期目選出委員5名) 今後選出予定

(2期目継続委員 5 名）：

大藤弘明, 河上哲生, 川本竜彦, 永嶌真理子, 安東淳一(委員長)

（18）日本鉱物科学会応用鉱物科学賞選考委員会：

委員 10 名で, 毎年その半数が交代し, 再任は妨げない。

委員長 : 佐藤 努 副委員長 : 今後選出予定

委員：(1期目選出委員 5 名) 今後選出予定

(2期目継続委員 5 名 $)$ ：

土屋範芳, 宮脇律郎, 柳澤教雄, 吉朝朗, 佐藤努(委員長)

（19）研究発表優秀賞選考委員会 : 委員長により指名

委員長 : 奥村 聡 副委員長 : 今後選出予定

委員 : (1期目委員 5 名選出) 今後選出予定

(2期目継続委員 5 名 $)$ :

岡本敦, 永嶌真理子, 中野伸彦, 森下知晃, 奥村聡(委員長)

(20) 2017年年会運営委員会

2017年年会運営委員会 : 入舩徹男委員長, 総括

委員: 井上 徹, 土屋卓久, 大藤弘明, 西原 遊, 土屋 旬, 境 毅, 大内智博, 西 真之, 森 寛志, 齊藤 哲, 榊原正幸, 佐野 栄 黒澤行事委員長，角替副行事委員長，磯部副委員長

第3号議案 平成28年度事業計画および収支予算書承認の件

1. 事業計画案について:土山会長より以下の説明があり承認され た。

1）編集事業 : 岩石鉱物科学の発行, Journal of Mineralogical and Petrological Sciencesの発行

2) 行事事業 : 2017年年会 (愛媛大学) の開催 平成28年度第1回

3）各賞の表彰事業 定時社員総会の開催

4） その他

2. 平成28年度収支予算案について

土山会長から以下の説明があり，承認された。

社員総会開催を9月中にしか開催できないことから社員総会開催ま での諸手続き上，7月決算としたので，初年度だけ11か月で運営す ることとした。以下は総会までの手続き。

7月末年度運営終了, 決算

8月決算計算書類作成，事業報告作成，監事の監查を受ける。 理事会開催通知，社員総会開催日の2週間前以上には理事会 開催して承認を受け，社員総会開催通知を出す。

第4号議案 運営細則等各規約検討作業の件

細則等検討委員会に諮問することとなり, 委員会発足後, 大和田 特務幹事を中心に第2回理事会まで答申寸ることが承認された。

第5号議案 2019年年会開催地の件

黒澤行事幹事から引き続き検討することが報告され，承認された。
平成28年度会計収支予算

(平成28年9月1日 平成29年7月31日)

\begin{tabular}{|c|c|}
\hline 収入 の 部 & 予 算 \\
\hline 会費収入 & $8,004,400$ \\
\hline 一般会員 & $5,000,000$ \\
\hline 学生会員 & 350,000 \\
\hline シニア会員 & $1,000,400$ \\
\hline 永年・名誉会員 & 24,000 \\
\hline 購読会員 & 930,000 \\
\hline 賛助会員 & 300,000 \\
\hline 前年度分 & 400,000 \\
\hline 出版物収入 & $2,000,000$ \\
\hline 雑 収入 & 45,000 \\
\hline 広告収入 & 160,000 \\
\hline 年会収入 & $2,600,000$ \\
\hline 事業活動 収入 小 計(1) & $12,809,400$ \\
\hline 事業活動前年度繰越金 & $5,433,186$ \\
\hline 学会誌等刊行基金 前年度繰越金 & $3,476,946$ \\
\hline 学会賞・奨励賞・論文賞基金 前年度繰越金 & $1,620,503$ \\
\hline 渡邉萬次郎賞基金 前年度繰越金 & 170,562 \\
\hline 国際学会·年会基金, 学会活動支援基金 前年度繰越金 & $2,278,978$ \\
\hline $\begin{array}{l}\text { 前年度繰越金 小計(2) } \\
\end{array}$ & $12,980,175$ \\
\hline 収 入 合 計 (1) + (2) & $25,789,575$ \\
\hline
\end{tabular}

\begin{tabular}{|c|c|}
\hline 支 出 $の$ 部 & 予 算 \\
\hline 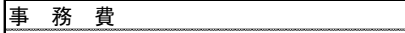 & $4,515,000$ \\
\hline 消耗品費 & 5,000 \\
\hline 通信費 & 120,000 \\
\hline 人件費 & $4,090,000$ \\
\hline 旅費・交通費 & 150,000 \\
\hline 物件費 & 70,000 \\
\hline 委託費 & 180,000 \\
\hline 租税公課 & 150,000 \\
\hline 刊 行 費 & $4,300,000$ \\
\hline 会誌出版費 & $2,900,000$ \\
\hline 送料・その他 & $1,000,000$ \\
\hline 英文校閲費 & 400,000 \\
\hline 集 会 費 & $2,750,000$ \\
\hline 年会開催費 & $2,600,000$ \\
\hline 会議費 & 150,000 \\
\hline 連合団体会員年会費 & 10,000 \\
\hline 雑 費 & 500,000 \\
\hline 予 備 費 & 30,000 \\
\hline Elements & $1,700,000$ \\
\hline $\begin{array}{rrr}\text { 事業活動 } & \text { 支出 小計 (3) } \\
\end{array}$ & $13,805,000$ \\
\hline 学会誌等刊行基金 & 0 \\
\hline 学会賞·奨励賞·論文賞基金 & 270,640 \\
\hline 渡邊萬次郎賞基金 & 55,000 \\
\hline 国際学会·年会基金, 学会活動支援基金 & 106,160 \\
\hline 基金支出 小 計 (4) & 431,800 \\
\hline 支出合計(3) + (4) & $14,236,800$ \\
\hline 次年度繰越金合計 & $11,552,775$ \\
\hline 支出合計 & $25,789,575$ \\
\hline
\end{tabular}

第6号議案 法人化記念事業の一環としての鉱物・岩石寄贈の件

伴広報幹事から以下のような修正案が提案され承認された。

「鉱物・岩石の試料の寄贈について」修正案

この度の一般社団法人化の記念事業の一環として, 年会やJpGU での展示利用など, 日本の鉱物科学の発展につながる事業で活用さ せていただく鉱物・岩石の本学会への寄贈を募集します。

ご退職教員などで試料の廃棄をお考えの方は, 鉱物科学の普及活 動に使えそうな標本を提供いただけますと幸いです。ご提供可能な 方は下記条件にて, 日本鉱物科学会へ試料のご寄贈をお願いしま す。・一般人(特に中高生〜大学の学部学生)の興味を引きそうな試 料。・標本の永続的保存を目的としたものではありませんので, 学 術的に貴重な標本は除外願います。・立派な試料(結晶形が美しいな ど）・一人数個まで。・最も長い部分が $10 \mathrm{~cm}$ 程度まで。・一般向け に頒布しても良いもの（JpGUのブースなどでの頒布を考えていま 寸)（取り扱いに公の許可が必要な可能性のある試料や放射性鉱物 はお断りします)。・学会への送料, 返送費用は寄贈者のご負担にて 
お願いいたします。・添付の譲渡承諾書もご提出下さい。

- 提出方法

日本鉱物科学会学会事務局へお送りください。添付の譲渡承諾書 のご提出を忘れないでお願いします。

•お断り

試料は学会にて「寄贈品として相応しいか」を確認させていただ きます。相応しい試料でないと判断された場合は，着払いの宅配便 で返送させていただきます。寄贈下さった方のお名前は学会ウェブ などで紹介させていただきます。

第7号議案 IMA分科会の件

土山会長により状況の説明があり, 継続して将来企画委員会に諮 問することが承認された。

第8号議案 佐藤会員幹事より

（1）新法人定款第 10 条（会員資格の喪失）による平成 28 年度からの 「会員資格喪失」対象者の対応につて

平成 28 年 8 月 31 日時点で 2 年会費未納者 17 名についての平成 28 年度の対応について審議の結果, 今回も関係各位に対応をしてい ただき今年いっぱい保留にすることで承認された。

但し, 今後は定款「定款第10条（会員資格の喪失）第(3)項 第7 条の年会費の支払義務を2年以上履行しなかったとき。」に従い「会 員資格喪失」となる。また，会員会費規定第3 条「権利」「第4項年 会費の支払義務を 2 年以上履行しなかったときは, 会員資格及び第 1項の権利を喪失する。ただし, 未履行の義務についてはこれを免 れない。」も併せて該当することの説明があった

(2) 継続審議の「外国人留学生学生正会員の帰国後のサポートに関 するガイドライン」の件 継続して検討することで承認された。

その他

以下の将来企画委員会継続議題を確認し, 将来企画委員会発足後 継続して諮問し，第2回理事会までに答申寸ることが承認された。

(1) 外部団体からの受賞候補者推薦(学振賞, 育志賞, 文部科学大臣 表彰，IMAメダルなど)の推薦システムの検討

(2) 研究発表優秀賞の表彰式の件 あわせて年会クロージングセレモニーの実施などで次の開 催年会への引継ぎを行う件。

(3) 理事の人数の件 適正な理事の人数を検討することとともに, 幹事についても 検討すること。

(4) 年会アブストラクトの電子化について」見積もりをとること。

8. 閉会

以上の議事を終え，18時 00 分に閉会した。

上記の決議を明確にするため, 出席した会長, 副会長及び監事がこ れに記名押印する。

平成29年5月19日

$\begin{array}{lll}\text { 会長 } & \text { 土山 明 } & \text { 印 } \\ \text { 副会長 } & \text { 榎並正樹 } & \text { 印 } \\ \text { 監事 } & \text { 小山内康人 } & \text { 印 } \\ & \text { (捺印配布時省略) } & \end{array}$

\section{平成28年12月26日理事会 (決議の省略による) 議事録}

1. 理事会の決議があったものとみなされた事項の内容

第1号議案「各委員会選出のための関連内規，規定改定案」 第2号議案「岩石一水相互作用研究部会の設立申請」

2.1 の事項の提案をした理事の氏名 : 理事 土山 明

3．理事会の決議があったものとみなされた日：

平成 28 年12月26日

4. 議事録の作成に係る職務を行った理事の氏名：

会長 甫山 明

上記のとおり，一般社団法人及び一般財団法人に関する法律第 96 条 (第197条において準用する第96条) 及び定款第30条第2項の規定に より, 理事会の決議があったものとみなされたので, 理事全員の同 意があったこと及び監事の異議がなかったことを証するため, 本議 事録を作成し，議事録作成者が記名押印する。

平成 28 年12月26日

一般社団法人日本鉱物科学会

議事録作成者 会長 土山 明印

（捺印配布時省略） 